\title{
ECONOMIC STUDIES ON UNORGANIZED DAIRY FARMS IN JAIPUR REGION OF RAJASTHAN
}

\author{
Jitendra Kumar Sharma ${ }^{1}$, Narendra Kumar Singh ${ }^{2 *}$ \\ School of Agriculture, Suresh Gyan Vihar University, Jaipur, Rajasthan, 302017 (India) \\ For correspondence:.Jitendra.kumar@mygyanvihar.com
}

\begin{abstract}
The present study was undertaken to estimate the costs and returns of milk production of unorganized dairy farms in Jaipur region of Rajasthan using dairy owner's level data from 50 unorganized dairy farms of 5 districts namely Alwar, Dausa, Jaipur, Jhunjhnu and Sikar. The study was based on primary data collected through structured interview schedule. Production performance of each milch animal was calculated by taking the average cost and milk yield (liter/day/animal). The study revealed that among all cost components, total feed and labour cost were the major cost components. Feed cost varied from $\mathbf{5 4 . 2 2}$ to $\mathbf{5 7 . 0 7}$ percent in local cows to $\mathbf{5 7 . 0 7}$ percent in buffaloes and labour cost was varied from 33.87 percent to 34.45 percent. Contribution of total variable cost was varied from 90.56 to 94.08 percent. The average total maintenance cost for local cows per liter in unorganized dairy farms was worked out to be Rs.174.07 /animal/day. It was quite higher for a crossbred/exotic cows Rs.364.18/animal/day followed by Rs.345.86/animal/day. Despite the higher milk production cost, the cost of milk production of crossbred/exotic cows was lower Rs.24.71/litre/day than the local cows and buffaloes due to the better milk production performance. The maintenance cost was observed lowest in rainy season in all milch animals due to availability of green fodder in sufficient amount. The analysis indicates that all breeds of milch animals maintained by dairy owners in Jaipur region were profitable by minimum average net returns per animal/per day which were recorded Rs.56.18 from local cows to maximum Rs. 175.64 case of Cross Bred/Exotic cows whereas buffaloes contributes Rs.106.591. Similarly, the Benefit-Cost (B-C) ratio was also found maximum (1.44) in cross breeds/exotic cows and minimum 1.25 for local cows. Thus the study revealed that Indian premier cross breeds/exotic cows were superior to local cows and buffaloes in generating income in Jaipur region because of the milk production performance.
\end{abstract}

Keywords: Fixed Cost, Variable cost, Jaipur region, Milk production, B-C ratio.

\section{Introduction}

Dairying is an important subsidiary enterprises in rural and closely attached urban area of Rajasthan in terms of income and expenditures, thereby looking to this the present study was purposely conducted in one of the most important milk producing region of Rajasthan and all five districts of Jaipur region namely Alwar, Dausa, Jaipur, Jhunjhunu and Sikar were selected for collecting desirable information's through a well constructed data schedule from selected un organized dairy farms.

The cost and returns in dairy enterprises are important aspects for milk producers, consumers and policy makers and planning organizations such as govt. and animal husbandry departments to provide an effective input for making rational economic decisions. In this respects though no. of attempts have been made on estimation of cost and returns in dairying in the country (Nagarale et al 2007, Singh and Agrawal 2007, Bhowmick and Sirohi 2008, Bardhan and Sharma 2012 ,Chand and Sirohi 2012,Singh et al 2012,Gupta et al. 2014, Deshetti M. B. et al 2017 and Pragya Joshi et al (2018).Therefore, in view of this, present study was conducted on cattle and buffaloes of randomly selected un organized dairy farms run by privately mostly by farmers having their own agricultural land.

\section{Material and methods}

The present study was carried out with the specific objectives to estimate the milk production cost and returns from various species of dairy animals using standard methodology and to identify the major detriments and production traits influencing the economics of dairy business in Jaipur region of Rajasthan. The methodology for estimation of costs and returns in dairying is quiet older particularly the computation of capital cost etc. With the improved breeding practices, changing management practices and labour use and allocation patterns, costs and returns in milk production. The broad steps and major refinement made are discussed by Sirohi et al. (2015). Net profit was measured by subtracting the total expenditures on rearing of dairy animals from total returns by same groups. The inputs used in dairy farms for milk production were classified as a fixed and variable cost. The value of each component was added together to determine the fixed and variable cost for each animal. The relevant components of fixed cost included in milk production were interest and depreciation on fixed capital. The value of animal and cattle shed and other fixed items used in rearing the milch animals and milk production was taken 
to work out interest on fixed capital. The interest on working capital was not taken in to consideration as the house hold gets income from milk every day. The interest rate on cattle and cattle shed was worked out @ $12.5 \%$ per annum considering the prevailing interest rate of various financial institutions. The depreciation on milch local cow as was charged @8.34\% assuming 12 years as a productive life cycle.

Variable costs included those recurring components in milk production, which are incurred on feed and fodder, labour expenses, expenditures on breeding and healthcare management and miscellaneous expenses like electricity etc. The total cost was worked out with adding together total fixed total variable cost . The net cost arrived after deductions, the value of the dung from total cost and net income was obtained after the deduction of net cost from the value of milk production. The gross returns on per house hold per day was obtained with the by adding the value of milk produced and dung value by multiplying the price of milk per litre and price of dung per $\mathrm{kg}$.

\section{Production performance of animals}

The production traits like Age at first calving, lactation period, calving interval, Conception success through Artificial Insemination success score, Steaming - up, Dry periods also assessed during study.

\section{Result and discussion}

Study reveals that the average herd size under the study of 50 dairy farms having 45.99 animals /per dairy farms (table 01). Out of this, Indigenous cows were 13.73 and, exotic and cross bred cows were 26.16 and no. of buffaloes was 6.1. The adult milch animals were recorded 8.04, 20.26 and 4.36 of local cows, Exotic and cross bred cows and buffaloes are respectively ( Joshi et al (2018). The production traits like Age at first calving, Lactation period, calving interval, Conception rate through A.I. success score, steaming-up, Dry periods, also assessed during research.

Table - 01

\begin{tabular}{|l|c|c|c|c|}
\hline \multicolumn{5}{|c|}{ Average Herd Size in Jaipur Region of Rajasthan } \\
\hline Particular & Indian Cow & Ex.Cow/Cross bred cow & Buffaloes. & Average \\
\hline i.In Milk (Pregnant) & 4.84 & 10.74 & 2.22 & 17.8 \\
\hline ii.In Milk (Not Pregnant) & 1.64 & 5.56 & 1.28 & 8.48 \\
\hline Total (Milch Ind.Cow) & 6.68 & 16.14 & 3.54 & 26.36 \\
\hline iii.Dry Pregnant & 0.9 & 2.32 & 0.62 & 3.84 \\
\hline iv.Dry not Pregnant & 0.46 & 1.8 & 0.2 & 2.46 \\
\hline Total & 8.04 & 20.26 & 4.36 & 32.66 \\
\hline v.Heifers & & & & 0 \\
\hline 1 Pregnant & 1.16 & 1.9 & 0.8 & 3.86 \\
\hline 2.Not Pregnant & 1.52 & 2.42 & 0.56 & 4.5 \\
\hline Total Young Stock & 3.52 & 5.9 & 1.74 & 11.16 \\
\hline vii.Draught animal & 2.17 & & & 2.17 \\
\hline Total Livestock & 13.73 & 26.16 & 6.1 & 45.99 \\
\hline
\end{tabular}

In respect of production traits (table -2a.)of various types of milch animals, it was recorded that the age at first calving was less 31 months in cross bred/exotic cows than the local cows (35 months). The age of first calving in buffaloes was recorded 42 months. The lactation length was also recorded higher (290 days) in exotic and cross bred cows as compare of local cows(253 days). The length of dry period was higher in local cows 70 days in comparison to cross bred/exotic cows (64 days),but in local cows inter calving periods were found having more time (383 days) against cross bred (378 days).In every cases production traits was recorded higher in buffaloes by nature than the local and cross bred cows. 
Table.2a Production traits of milch animals

\begin{tabular}{|c|c|c|c|c|c|c|}
\hline \multicolumn{4}{|c|}{ Age at first Calving(in Months) } & \multicolumn{3}{c|}{ Inter calving intervals(days) } \\
\hline Districts & Cross Bred/Exootic & Indigenous Cow & Buffaloes & Cross Bred/Exootic & Indigenous Cow & Buffaloes \\
\hline Alwar & 29 & 36 & 38 & 378 & 377 & 416 \\
\hline Dausa & 32 & 34 & 42 & 385 & 379 & 411 \\
\hline Jaipur & 28 & 33 & 41 & 368 & 388 & 398 \\
\hline Jhunjhnu & 34 & 38 & 44 & 370 & 384 & 402 \\
\hline Sikar & 32 & 35 & 45 & 387 & 388 & 399 \\
\hline Region & 31 & 35.2 & 42 & 377.6 & 383.2 & 405.2 \\
\hline \multicolumn{2}{|c|}{} & Lactation -Length(Days) & & & Dry Periods(days) & \\
\hline Districts & Cross Bred/Exootic & Indigenous Cow & Buffaloes & Cross Bred/Exootic & Indigenous Cow & Buffaloes \\
\hline Alwar & 285 & 260 & 303 & 65 & 72 & 94 \\
\hline Dausa & 295 & 240 & 295 & 62 & 66 & 92 \\
\hline Jaipur & 305 & 270 & 298 & 58 & 69 & 88 \\
\hline Jhunjhnu & 288 & 240 & 287 & 64 & 72 & 97 \\
\hline Sikar & 276 & 255 & 301 & 72 & 68 & 86 \\
\hline Region & 289.8 & 253 & 296.8 & 64.2 & 69.4 & 91.4 \\
\hline
\end{tabular}

Further Table. $2 \mathrm{~b}$ reveals about the success rate of Artificial Insemination (A.I.) in the study area is still matter of concern and it was recorded that conception success by Artificial Insemination (A.I.) was below 53.66\% among Exotic/cross bred cows, $48.10 \%$ in indigenous cows and lowest 39.5\% among buffaloes. The lower conception adversely affects the economics of dairying.

In the study area the practice of extra care of pregnant animals by dairy owners recorded on positive aspects that all the farms following the practice of Steaming -up practice without knowing the technical name of this extra nutrition for pregnant female for obtaining and enhancing possibilities higher yield in coming lactation. Table $2 b$ reflects that dairy owners taking extra care to their milch animals were pregnant and their calving was very near. Dairy owners of the study area provides good feeds and fodder and other caring management practices in advance of about 23 days for cross bred cows and 18 days for local cows. However steaming days for buffaloes was higher about 28 days. These analysis shows that dairy owners in study area are cautious about their pregnant milch animals.

Table 2b.

\begin{tabular}{|c|c|c|c|c|c|c|}
\hline \multicolumn{4}{|c|}{ Conception sucesses by A.I.(Success Score of A.I.) } & \multicolumn{4}{c|}{ Steaming -up (In days) } \\
\hline & & Indigenous Cow & Buffaloes & Cross Bred/Exootic & Indigenous Cow & Buffaloes \\
\hline Alwar & 54.3 & 51.5 & 40 & 21 & 15 & 28 \\
\hline Dausa & 53.8 & 52.5 & 42 & 26 & 13 & 29 \\
\hline Jaipur & 54.5 & 46 & 42 & 20 & 16 & 27 \\
\hline Jhunjhnu & 50 & 46 & 39.5 & 28 & 21 & 29 \\
\hline Sikar & 53 & 42 & 41 & 19 & 24 & 28 \\
\hline Region & 53.36 & 48.1 & 39.5 & 22.8 & 17.8 & 28.2 \\
\hline
\end{tabular}




\section{Feeding pattern}

Qualitative and quantitative feeding in animals specially for maintaining their quantitative and quality produce. Each types of animals having their own category of animal feed which contains all the essential nutrients required for their well being. Thus analysis of the fodder supplied to their milch animals was under taken during the present study and quantity of the various types of feed and fodder given by un organized dairy owners is represented in Table 3.

Table 3 shows that on an average dry fodder per animal were estimated as $5.3 \mathrm{~kg}, 12.5 \mathrm{~kg}$ and $11.02 \mathrm{~kg} / \mathrm{animal} / \mathrm{day}$ for local cows, exotic/cross bred and buffaloes respectively. However in case of green fodder, dairy owners provided $4.79 \mathrm{Kg}, 9.78 \mathrm{Kg}$ and $9.83 \mathrm{Kg}$ /animal/day for Local, Exotic/Cross bred cows and buffaloes respectively. The major source of feed and fodder was stalled feeding and grazing was not a common practice ( Chand et al 2018).

Table-3

\begin{tabular}{|l|c|c|c|c|}
\hline \multicolumn{5}{|c}{ Season wise feeding patern in Jaipur Region (kg/day/animal) } \\
\hline \multirow{2}{*}{ Components } & \multicolumn{2}{|c|}{ Local /Indigenous Cows/Kg/day/Animal } \\
\cline { 2 - 5 } & Summer & Rainy & Winter & Average \\
\hline Dry Fodder Kg & 6.54 & 3.6 & 5.8 & 5.31 \\
\hline Green Fodder Kg & 3.46 & 6.54 & 4.36 & 4.79 \\
\hline Concentrates Kg & 2.87 & 2.87 & 2.87 & 2.87 \\
\hline Mineral Mixture (GMs) & $52.3 \mathrm{Gm}$ & $52.3 \mathrm{Gm}$ & $52.3 \mathrm{Gm}$ & $52.2 \mathrm{Gm}$ \\
\hline Liq.Supplements (ML) & $63 \mathrm{ml}$ & $64 \mathrm{ml}$ & $65 \mathrm{ml}$ & $63 \mathrm{ml}$ \\
\hline \multirow{2}{*}{ Components } & Cross bred/Exotic Cows/Kg/day/Animal \\
\cline { 2 - 6 } & Summer & Rainy & Winter & Average \\
\hline Dry Fodder Kg & 11.78 & 11.96 & 13.02 & 12.25 \\
\hline Green Fodder Kg & 6.27 & 11.6 & 11.48 & 9.78 \\
\hline Concentrates Kg & 5.37 & 5.37 & 5.37 & 5.37 \\
\hline Mineral Mixture (GMs) & $114.5 \mathrm{Gm}$ & $114.5 \mathrm{Gm}$ & $114.5 \mathrm{Gm}$ & $114.5 \mathrm{Gm}$ \\
\hline Liq.Supplements (ML) & $119 \mathrm{ml}$ & $119 \mathrm{ml}$ & $119 \mathrm{ml}$ & $119 \mathrm{ml}$ \\
\hline \multirow{2}{*yyyyy}{} & & \multicolumn{3}{|c|}{ Buffaloes/Kg/day/Animal } \\
\hline Components & Summer & Rainy & Winter & Average \\
\hline Dry Fodder Kg & 11.96 & 8.8 & 12.3 & 11.02 \\
\hline Green Fodder Kg & 5.84 & 11.26 & 12.38 & 9.83 \\
\hline Concentrates Kg & 5.59 & 5.59 & 5.59 & 5.59 \\
\hline Mineral Mixture (GMs) & $93.6 \mathrm{Gm}$ & $93.6 \mathrm{Gm}$ & $93.6 \mathrm{Gm}$ & $93.6 \mathrm{Gm}$ \\
\hline Liq.Supplements (ML) & $128 \mathrm{ml}$ & $128 \mathrm{ml}$ & $128 \mathrm{ml}$ & $128 \mathrm{ml}$ \\
\hline \multirow{2}{*yyyy}{} & & & & \\
\hline
\end{tabular}

Wheat Straw was used as dry fodder however Lucerne and Berseem supplied as green fodder in general. Concentrates that were fed to the pregnant and milch animals comprised of cotton seed cake, mustered cake also broken grains of rice, wheat and bajra used so commonly for preparation of concentrate mix.

\section{Cost of milk production and income from dairying}

Cost and returns from milk production are directly related to productivity of animals. Higher cost leads to low cost of milk production and high returns with the given prices. Table $4 \mathrm{a}, \mathrm{b}$ and c reveals the average productivity of milch local cows is region was 6.05Litre/day/animal, Cross bred /Exotic cows 15.29 Litre/day/animal was quite higher against local cows and buffaloes average productivity recorded-7.84 Litre/day/animal (Sirohi et al., 2015). 
Table-4a,b \&c.

Table 4 a

\begin{tabular}{|c|c|c|c|c|c|}
\hline \multicolumn{6}{|c|}{ Maintenance cost of local cow (Rs./day/animal) } \\
\hline Components & Summer & Rainy & Winter & Average & \multirow{2}{*}{ \% Cont. } \\
\hline A-Fixed Cost & & & & & \\
\hline Interest on fixed capital & 14.1 & 14.1 & 14.1 & 14.1 & 8.10 \\
\hline Depreciation & 2.34 & 2.34 & 2.34 & 2.34 & 1.34 \\
\hline Total Fixed Cost & 16.44 & 16.44 & 16.44 & 16.44 & 9.44 \\
\hline \multicolumn{6}{|l|}{ B-Vaiable Cost } \\
\hline Dry Fodder & 13.08 & 10.8 & 14.5 & 12.793 & 7.35 \\
\hline Green Fodder & 17.3 & 16.35 & 26.16 & 19.937 & 11.45 \\
\hline Concentrate & 54.53 & 54.53 & 54.53 & 54.53 & 31.33 \\
\hline Mineral Mix 8.000 & 3.5 & 3.5 & 3.5 & 3.5 & 2.01 \\
\hline Liq.Feed Suppl. & 4.5 & 4.5 & 4.5 & 4.5 & 2.59 \\
\hline Total Feed Cost & 92.91 & 89.68 & 103.19 & 95.26 & 54.72 \\
\hline Labour cost & 58.60 & 55.60 & 62.66 & 58.953 & 33.87 \\
\hline Micella neous & 1.31 & 1.31 & 1.31 & 1.31 & 0.75 \\
\hline Veterinary,A.I. ,Insurance and other exp. & 2.11 & 2.11 & 2.11 & 2.11 & 1.21 \\
\hline Total Variable Cost & 154.93 & 148.70 & 169.27 & 157.63 & 90.56 \\
\hline Total Cost(A+B) & 171.37 & 165.14 & 185.71 & 174.07 & 100.00 \\
\hline Value of Dung & 11.52 & 13.12 & 11.78 & 12.14 & \\
\hline Net Cost & 159.85 & 152.02 & 173.93 & 161.93 & \\
\hline Milk Yield/Itr./day & 5.16 & 6.75 & 6.25 & 6.05 & \\
\hline Value of Milk Production & 180.6 & 236.3 & 237.5 & 218.12 & \\
\hline Net Income /Day & 20.75 & 84.23 & 63.57 & 56.18 & \\
\hline Cost per Ltr & 33.21 & 24.47 & 29.71 & 29.13 & \\
\hline Net Income /Itr & 4.02 & 12.48 & 10.17 & 8.89 & \\
\hline B-C Ratio & 1.05 & 1.43 & 1.28 & 1.25 & \\
\hline
\end{tabular}


Table $4 \mathrm{~b}$

\begin{tabular}{|c|c|c|c|c|c|}
\hline \multicolumn{6}{|c|}{ Maintenance cost of Cross Bred/Exotic cow (Rs./day/animal) } \\
\hline Components & Summer & Rainy & Winter & Average & \multirow[b]{2}{*}{$\%$ Cont } \\
\hline A-Fixed Cost & & & & & \\
\hline Interest on fixed capital & 18.2 & 18.2 & 18.2 & 18.2 & 5.00 \\
\hline Depreciation & 3.34 & 3.34 & 3.34 & 3.34 & 0.92 \\
\hline Total Fixed Cost & 21.54 & 21.54 & 21.54 & 21.54 & 5.91 \\
\hline \multicolumn{6}{|l|}{ B-Vaiable Cost } \\
\hline Dry Fodder & 29.4 & 32.58 & 32.55 & 31.51 & 8.65 \\
\hline Green Fodder & 53.3 & 48.1 & 72.4 & 57.933 & 15.91 \\
\hline Concentrate & 102.03 & 102.03 & 102.03 & 102.03 & 28.02 \\
\hline Mineral Mix 16.000 & 7.5 & 7.5 & 7.5 & 7.5 & 2.06 \\
\hline Liq.Feed Suppl. & 8.5 & 8.5 & 8.5 & 8.5 & 2.33 \\
\hline Total Feed Cost & 200.73 & 198.71 & 222.98 & 207.47 & 56.97 \\
\hline Labour cost & 133.20 & 125.60 & 131.24 & 130.01 & 35.70 \\
\hline Micella neous & 1.8 & 2.1 & 2.15 & 2.0167 & 0.55 \\
\hline Veterinary,A.I. ,Insurance and other exp. & 3.10 & 3.25 & 3.05 & 3.13 & 0.86 \\
\hline Total Variable Cost & 338.83 & 329.66 & 359.42 & 342.64 & 94.09 \\
\hline Total Cost(A+B) & 360.37 & 351.20 & 380.96 & 364.18 & 100.00 \\
\hline Value of Dung & 14.52 & 16.76 & 18.22 & 16.50 & \\
\hline Net Cost & 345.85 & 334.44 & 362.74 & 347.68 & \\
\hline Milk Yield/Itr./day & 11.47 & 17.92 & 16.49 & 15.29 & \\
\hline Value of Milk Production & 401.45 & 591.4 & 577.2 & 523.32 & \\
\hline Net Income /Day & 55.60 & 256.92 & 214.41 & 175.64 & \\
\hline Cost per Ltr & 31.42 & 19.60 & 23.10 & 24.71 & \\
\hline Net Income /ltr & 4.85 & 14.34 & 13.00 & 10.73 & \\
\hline B-C Ratio & 1.11 & 1.68 & 1.51 & 1.44 & \\
\hline
\end{tabular}


Table $4 \mathrm{c}$

\begin{tabular}{|c|c|c|c|c|c|}
\hline \multicolumn{6}{|c|}{ Maintenance cost of Buffaloe (Rs./day/animal) } \\
\hline Components & Summer & Rainy & Winter & Average & \\
\hline A-Fixed Cost & & & & & $\%$ Cont. \\
\hline Interest on fixed capital & 22.2 & 22.2 & 22.2 & 22.2 & 6.42 \\
\hline Depreciation & 3.55 & 3.55 & 3.55 & 3.55 & 1.03 \\
\hline Total Fixed Cost & 25.75 & 25.75 & 25.75 & 25.75 & 7.45 \\
\hline \multicolumn{6}{|l|}{ B-Vaiable Cost } \\
\hline Dry Fodder & 23.92 & 26.64 & 30.75 & 27.1 & 7.84 \\
\hline Green Fodder & 50.7 & 33.05 & 65 & 49.58 & 14.34 \\
\hline Concentrate & 106.21 & 106.2 & 106.2 & 106.2 & 30.71 \\
\hline Mineral Mix 14.500 & 7.5 & 7.5 & 7.5 & 7.5 & 2.17 \\
\hline Liq.Feed Suppl. & 7 & 7 & 7 & 7 & 2.02 \\
\hline Total Feed Cost & 195.33 & 180.40 & 216.46 & 197.4 & 57.07 \\
\hline Labour & 124.34 & 112.45 & 116.45 & 117.7 & 34.04 \\
\hline Micella neous & 1.8 & 2.1 & 2.15 & 2.017 & 0.58 \\
\hline Veterinary,A.I. ,Insurance and other exp. & 2.55 & 3.25 & 3.05 & 2.95 & 0.85 \\
\hline Total Variable Cost & 324.02 & 298.20 & 338.11 & 320.11 & 92.55 \\
\hline Total Cost(A+B) & 349.77 & 323.95 & 363.86 & 345.86 & 100.00 \\
\hline Value of Dung & 16.1 & 13.42 & 15.1 & 14.87 & \\
\hline Net Cost & 333.67 & 310.53 & 348.76 & 330.99 & \\
\hline Milk Yield/ltr./day & 6.28 & 9.57 & 7.66 & 7.84 & \\
\hline Value of Milk Production & 351.68 & 516.8 & 444.3 & 437.58 & \\
\hline Net Income /Day & 18.01 & 206.25 & 95.52 & 106.59 & \\
\hline Cost per Ltr & 55.70 & 33.85 & 47.50 & 45.68 & \\
\hline Net Income /Itr & -0.70 & 16.15 & 4.50 & 6.65 & \\
\hline B-C Ratio & 1.01 & 1.60 & 1.22 & 1.27 & \\
\hline
\end{tabular}

The average gross maintenance cost for local cows was worked out Rs.161.93/animal/day, the Gross maintenance cost for cross/exotic cows and buffaloes were quite higher than the local cows. it was Rs.364.18 for cross/exotic cows and Rs.345.86 for buffaloes, In gross maintenance cost, more than 90 percent was variable cost. Feed and fodder cost accounted higher ( 54 to $57 \%$ ) of gross income followed by labour cost ( 34 to $36 \%$ ) in all types of milch animals. The net maintenance cost was estimated lowest in local cows (Rs 161.93 /animal/day) against and Rs.330 .99 in buffaloes. The maintenance cost was lower in rainy season than winters and summers seasons .The 
per litre average cost of milk production was estimated Rs.29.13 for local cows Rs.24.71 for cross bred cow and it was quite higher Rs.45.60 for buffaloes. It was due to low milk production. Despite of higher maintenance cost, the cost of milk production of cross bred/exotic cows was quite lower (Rs.24.71/liter) than the local cows and buffaloes due to the better production performance.

The net profit margin per liter of milk from local cow s was Rs.8.89 and Rs. 6.65 for buffaloes and it was higher for cross/exotic cattle (Rs.10.73). Thus ,the cross/exotic cows were very profitable in the region as in case of other part of the country reported by several authors (Nagale et al 2007), Singh and Agrawal, 2007, Bhoumik and Sirohi, 2003, Bhardman and Sirohi, 2008, Chand and Sirohi, 2008, Jaiswal and Singh, 2015 followed by Chand et al (2018) and Joshi et al (2018).

\section{Conclusion}

Based on the survey results from 50 unorganized dairy farm of Jaipur region of Rajasthan, study concluded that rearing of buffaloes was not common in the study area and also was not profitable due to higher maintenance cost and lower productivity, similarly in case of local cows was also not profitable due to the poor performance. However the cross bred cows was economically viable due to higher productivity in spite of higher maintenance cost found.

\section{Acknowledgements}

The authors like to gratefully acknowledge to Head of School of Agriculture, Suresh Gyan Vihar University, Jaipur for providing necessary facilities during my present investigation.

\section{Disclosure statement}

No potential conflict of interest was reported by the authors

\section{Funding}

Nil

\section{References}

[1] Bardhan, D., Sharma, M L. 2012. Economics of milk productionin Kumaun region of Uttarakhand. Indian Journal of Dairy Science. 65(5): 416-22.

[2] Bardhan, D., Sharma, M.L. Saxena, R. 2010. Livestock in Uttarkand: Growth pattern and determinants of composition and intensity. Indian Journal of Animal Science. 80(6): 584-89.

[3] Beyero, N., Kapoor, V ., Tewatia, B S. 2015. Effect of roughageto concentrate ratio in the diet on milk production and fattyacid profile of milk in crossbred cows. Indian Journal of Dairy Science. 32(4): 373-78.

[4] Bhowmik, P., Sirohi, S. 2008. Cost of milk production and returns from dairying in South Tripura. Indian Journal of Dairy Science .61(4): 303-07.

[5] Bhowmik, P., Sirohi, S., Dhaka, J. P. 2007. Gains from crossbreeding of dairy cattle in the North East: Micro evidencefrom Tripura. Indian Journal of Agricultural Economics . 61(3):305-13.

[6] Borah, M., Halim, R.A. 2014. Dynamics and Performance of Livestock and Poultry Sector in India: A Temporal Analysis. Journal of Academia and Industrial Research. 3(1): 1-9.

[7] Chand ,P., Sirohi, S. 2012. Dairying in semi-arid eastern zone of Rajasthan: Input productivity and net returns. Indian Journal of Dairy Science., 65(1): 79-83.

[8] Chand, P., Sirohi, S., Mishra, A., Chahal, V.P. 2017. Estimation of costs and returns from dairying .in Malwa region of Madhya Pradesh. Indian Journal of Dairy Science. 87(3): 381-86.CSO. 2017.

[9] Deshetti, M. B., Teggi, M. Y., Hosamani, S. V. 2017. Milk production and resource use efficiency of dairy farming understall-fed condition in Karnataka. Indian Journal of Dairy Science. 70(4): 466-70.

[10] Elumalai, K., Pandey, U.K. 2003. Growth and density of livestock and poultry in Haryana. Indian Journal of Animal Science. 73: 11681173.

[11] Garg, M. R., Kannan, A., Phondba, B. T., Shelke, S. K., Sherasia, P.L. 2012. A study on the effect of ration balancing for improving milk production and reducing methane emission in lactating buffaloes under field conditions. Indian Journal of Dairy Science. 63(3): $250-55$.

[12] Gauraha, A. K. 2007. Economics of milk marketing in Chhattisgarh. Indian Journal of Agriculture Economics. 62(3):463-64.

[13] Gupta, J. J,, Singh, K. M., Bhatt, B. P., Dey, A. 2014 . A diagnostic study on livestock production system in eastern region of India. Indian Journal of Dairy Science. 84(2): 198-203.

[14] Jaiswal, P., Singh, R. K. 2015. Economics of milk production and determinants of market participation for small holder dairy farmers in Raipur district of Chhattisgarh. Indian Journal of Dairy Science 68(6): 619-28.

[15] Joshi P et al .2018 .Economics of Badri cattle rearing in Uttrakhand,Indian. Journal of Animal Sciences 88(8):977-978.

[16] Kaur, P., Bhullar, A. S. 2012. Structure of Milk Production in Punjab-An Analysis of Trends and Sources of Growth. Indian Journal of Dairy Science., 65(6): 514-519.

[17] Nagrale, B. G., Datta, K. K., Singh, S. R. 2007. Cost of milk production in Vidarbha region of Maharashtra. Indian Journal of Dairy Science. 64(6): 514-19.

[18] Prem Chand et al 2018. How profitable is dairying in tribal Chattisgarh?. Indian Journal of Animal Sciences 88(6):749-754.

[19] Lal, P., Chandel, B.S. (2016).Economics of milk production and cost elasticity analysis in Sirsa district of Haryana Economic Affairs Citation: EA: 61(3): 405-411.

[20] Sharma ,A. 2013. 'Economic viability of commercial dairy farms in Jabalpur district of Madhya Pradesh.'M.Sc Dissertation ,National Dairy Research Institute, Karnal.

[21] Sharma, V.P. 2004. Livestock economy of India: current status, emerging issues and long-term prospects. Indian Journal of Agriculture Economics. 9(3): 512-544.

[22] Singh K R, Agarwal S B and Malhotra R. 2007. Resource-use efficiency in milk production and disposal of milk in Imphal West district of Manipur. Indian Journal of Dairy Science. 60(3): 213-17. 
[23] Singh, R.K., Agarwal, S. B. 2007. Economics of milk production in Imphal west district of Manipur. Indian Journal of Dairy Science 60(6): 441-46.

[24] Sinha, M. K., Dhaka, J. P., Meena, M. S. 2012. Milk production economics and micro financing impacts in Chhotanagpur plateau of Jharkhand. Indian Journal of Animal Sciences .82(7):757-61.

[25] Sirohi, S., Saxena, R., Chauhan, A .K., Dhaka, J. P., Sirohi, S. K., Kumar, N,. Sharma, D., Pal, K., Agrawal, P., Sharma, A., Kumar, S., Feroze, S. M., Burdhan, D., Kumar, S., Chand, P. Fulpagare, Y. G 2015. Costs and returns in milk production: Developing standardized methodology and estimates for various production systems. Project report Submitted to Department of Animal Husbandary, Dairying and Fisheries, Ministry of Agriculture, Govt. of India, New Delhi.

[26] Subhash, S. P., Kaur, P. 2013. Livestock Population in Punjab: Factors Determining Growth, Composition and Density. Journal of Agriculture and Develop Policy. 23(2): 79-91.

[27] Tanwar, P.S., Kumar, Y., Sankhala, G. 2012. Economics of milk production among member and non-member families of dairy cooperatives in Jaipur (Rajasthan). Indian Journal of Dairy Science 65(5): 405-409.

[28] Vashist, G.D., Katiha, P. 1988. A comparative economic analysis of milk production for different milch animals in Himachal Pradesh. Agrilcultural Situation in India. 43(2): 133-138.

[29] Venkatesh, P., Sangeeta, V. 2011. Milk production and resource use efficiency in Madurai district of Tamil Nadu: An economic analysis. J Comm Mob Sust Dev 6(1): 025-030. 